\title{
Postpandemic futures of Global Citizenship Education for preservice teachers: Challenges and possibilities
}

\author{
Allison Witt ${ }^{1}$
}

Accepted: 12 January 2022

(C) The Author(s) under exclusive licence to UNESCO International Bureau of Education 2022

\begin{abstract}
Rather than returning to prepandemic normal, initial teacher education (ITE) must reexamine strategies to instill global citizenship education (GCE) skills in all preservice teachers. This article considers the impact of higher education's neoliberal internationalization context on efforts to provide GCE to preservice teachers in university-based teacher education. Examining study abroad, one prominent example of GCE in ITE, reveals how higher education's neoliberal internationalization practice limits potential transformation. This article asserts that ITE should follow school and community partnership models based on education theories that value diversity and social justice. Theories of boundary crossing offer one approach for reimagining study abroad for GCE in ITE and may have implications for other efforts at GCE for preservice teachers. In this moment, ITE must radically reimagine GCE in response to the generation of students and teachers who know they live in a deeply connected, unjust world.
\end{abstract}

Keywords Global citizenship education - Preservice teacher training · Higher education · Internationalization $\cdot$ Covid-19 $\cdot$ Study abroad

Never before in history has all of humanity so closely shared a global contemporaneous experience as with the Covid-19 pandemic. Everyone worldwide has experienced the trauma and response and shared it across social and other media. The global suffering has further highlighted societal inequities. Calls for social justice found echoes around the world in reverberating collective demands even as the pandemic forced social distance. Now, schools worldwide struggle to "get back to normal", but surely there is no going back after such a multifaceted global disruption?

Allison Witt

awitt1@illinois.edu

1 College of Education, University of Illinois Urbana-Champaign, 1310 S. 6th Street, Champaign, IL 61820, USA 
When P-20 schools closed suddenly worldwide, teacher education (ITE) confronted challenges on two fronts: how to continue teaching, and, at the same time, how to prepare students to teach in a disrupted context. In addition to the collective societal loss, the inequalities brought to the forefront by the pandemic demand immediate response in ITE. Preservice education students will soon be new teachers stepping into communities upended both by the trauma of the pandemic and by the glaring issues of inequality raised globally.

Global citizenship education (GCE) both explains the current challenges and provides potential cures. Global connection is clear. Students across the P-20 spectrum know from personal experience that occurrences in one city may have a direct, immediate, and lasting impact on the entire world, including personal impacts to their own health, family, way of life, and schooling. Yet, how are students making sense of this global connection? Can educators inform this response and the interrelated social justice movements? The postpandemic moment holds extraordinary promise for teachers globally if, through GCE, awareness of global connection and the push for social justice can be harnessed toward global citizenship goals.

Just as students are changed by the pandemic, so too are teachers and the context of schooling. The imperatives of global connection underlie every level of education, every school, every classroom, every teacher, and every student. The pandemic demonstrated that humanity's global connection, as well as current social injustice, are foundational knowledge that all teachers in all subjects must be prepared to address. Even before the pandemic, scholars called for this reimaging (Gaudelli, 2016). ITE can no longer relegate GCE to an add-on or luxury only for those who can afford it, but instead must train all future teachers with this essential knowledge.

During the pandemic and in its aftermath, fear, xenophobia, and distrust of science seemed to grip the world. One need only glance at any newspaper worldwide or any social media to see examples. Yet, at the same time, the moment demonstrates the triumph of global science as well as our shared humanity. Rather than allow fear or isolationism to fester and spread among students, teachers around the globe must employ GCE to assert the possibilities of collaborative, global remedies for all global challenges. Having themselves experienced the pandemic, students are uniquely situated to recognize the necessity of global collaboration around health, social, political, economic, and environmental issues. If GCE is to realize this potential, it will require ITE to ensure that all teachers can impart GCE to current and future generations.

In the decades before the pandemic, ITE around the globe developed numerous strategies to instill GCE and related concepts in preservice teachers (Yemini et al., 2019; Pashby et al., 2020). Teacher educators created study abroad programs, globally focused cohorts, field experiences in diverse settings, and other classroom-situated practices to develop various aspects of GC in preservice teachers (Gaudelli, 2016). However, even as studies demonstrated efficacy in some of these models, researchers found that many of the practices were only available to subsets of teacher candidates and were rarely distributed equitably. Moreover, efforts at incorporating GCE were often limited to specific subjects, such as science and social studies, where it was assumed global topics "fit" (Bourn et al., 2017). Data suggests that without a national drive or external input for GCE in ITE, provision by teacher educators is ad hoc and limited (Bourn et al., 2017). As educators begin to (re) construct postpandemic education worldwide, teacher education must reimagine previous practices for the current context. Rather than simply returning to prepandemic normal, teacher education must reexamine GCE development for preservice teachers in order to instill GCE skills within all teacher candidates. 
Working from the heuristic of GCE developed by Gaudelli (2009), this article critiques previous models of GCE in ITE to reveal how higher education's neoliberal internationalization has infected GCE university-based teacher education. As Gaudelli notes, "one would be hard pressed to find a university in the US, for example, that does not invoke global citizenship... as part of its mission", yet at the same time, "one would be equally challenged to find such missions enacted" (2009, p. 69). While ITE employs numerous strategies toward GCE, the pandemic was clearly disruptive for study abroad. By taking this one ITE strategy for GCE, study abroad, as the example, this article asserts that university-based teacher education should not merely return to the neoliberal models of many of higher education's internationalization efforts. Instead, ITE should look to its own institutional partnership models based on education theories that value diversity and strive to achieve aims of social justice. Educational theories of boundary crossing offer one promising avenue for reimagining GCE. In this moment, ITE must radically reimagine the practice and possibilities of GCE for responding to the generation of students and teachers who know they live in a deeply connected, unjust world and need an immediate, coherent strategy for how to navigate and thrive in it.

\section{Defining GCE for postpandemic futures}

GCE is a contested concept with an array of definitions and interpretations (Goren \& Yemini, 2016; Bosio \& Torres, 2019). A number of useful typologies exist to delineate GCE (Oxley \& Morris, 2013; Goren \& Yemini, 2017; Pashby et al., 2020). I turn to Gaudelli (2009) for a robust heuristic of global citizenship concepts to apply to higher education internationalization practice and then to Shultz (2007), who has explicated a transformational perspective of GCE that the postpandemic context, in particular, demands.

Gaudelli's heuristics of global citizenship delineate five different conceptualizations: neoliberal, nationalist, Marxist, world justice/governance, and cosmopolitan. Neoliberal GCE, among the most prevalent, aims to construct global citizens who can successfully participate in a market economy organized by capitalism and driven by technology. Following neoliberal GCE means teaching citizens of the wealthiest nations that their role as global citizens is to compete in the global marketplace, while maintaining the structures of inequality that keep members of less wealthy countries marginalized. Gaudelli explains that such curriculum models champion competition, value academic learning, and are above all aimed at utility (2009, p. 71). A large body of research locates neoliberal framing in higher education internationalization practices, including study abroad (Burbules \& Torres, 2000; Popkewitz, 2007; Brown, 2011; Andreotti, 2015).

In a similar vein to Gaudelli, Shultz (2007) finds that global citizenship education efforts often correspond to one of three broad ideological agendas: neoliberalism, radicalism, or transformationalism. As noted, the neoliberal agenda for GCE celebrates the dominant global market and assumes that the goal for citizens is to be a successful market participant, with peoples and cultures valued on this scale. Put simply, rich countries are winning, and thus remain superior, within this framing. A radical approach, on the other hand, fosters citizens who critique the inequalities and injustices of this neoliberal approach and assume the responsibility to challenge state and corporate oppression. However, as Shultz explains, the radical approach can reify the current neoliberal structures, casting them as somehow fixed, with radical efforts aimed at different or more even distribution, without actually questioning why such structures must even exist (2007). 
Shultz suggests an alternative to this binary through GCE aimed at transformationalism. The transformational perspective requires an understanding of globalization that is multifaceted along cultural, social, environmental, political, and economic lines. Rather than endorsing the structures of neoliberal capitalism or assuming that such structures are fixed, transformationalism allows students to completely reimagine patterns of inclusion and exclusion. Instead of embracing neoliberal structures or working against them, transformationalism calls for the creation of new forms of engagement. From a transformational perspective, global citizens understand their deep connection to all humanity and their role in collaborating on issues that cross national boundaries. GCE in the transformationalism frame reimagines inclusive community and recognizes the link between the local experience and the shared global experience. Transformational GCE calls for new ways of structuring relations between and within nations and urges us to learn new ways of negotiating global relations. This transformation is what the current postpandemic moment requires of GCE.

\section{Transformational models for global relations within teacher education}

Teacher education might seem an unlikely place to look for models of global engagement. Comparing all disciplines worldwide, ITE is one of the most locally constructed, with licensure requirements tied to the national or even regional level. Yet, teacher education has a long tradition of working in partnership with institutions- that is, with local schools in teacher training partnerships. Globally, most university-based teacher training requires students to spend time away from the university campus, with teacher education students placed directly in schools as a critical part of their training. While these school and university collaborations have historically been fraught and complex, large bodies of research guide this relationship and its ongoing development from the traditional hierarchal model, in which the university dictated the terms of the arrangement, to a more equitable collaboration that values local teachers' contribution to the training project (Norman, 2011; Clarke et al., 2014). Of course, challenges to creating an equitable partnership remain, but a great deal of progress has been made globally in this area.

In fact, worldwide, strong collaborations between university-based teacher training and local schools mark the apex of teacher education. Scholars in Singapore, for example, attribute their national excellence in education to the seamless and unified objectives of ITE and the local schools, while large, diverse systems like the US continue to research and refine ways to improve this relationship viewed as critical to teacher education practice (Yuan \& Yang, 2020).

Critics have accurately noted the increasing neoliberal market impacts seeping into all aspects of $\mathrm{P}-12$ education. However, university and school relationships, and the critical role of the practicing teacher, are not primarily economically driven. In fact, according to Fives et al. (2016), in the US, compensation for cooperating teachers has stagnated or decreased since the late 1950s even though expectations of that role have increased dramatically. Such relationships exist within a power differential that teachers must negotiate, but strategies to create a more equitable collaboration are a source of ongoing investigation, research, and effort. Though this effort sometimes falls short, the collaboration between schools and university teacher education programs is driven not by market practices, but by a shared sense of responsibility and mutually recognized investment in the profession, with a dedication on both sides to the common good. 
A growing body of education theory research drives this dialogic turn in university and school partnerships. Drawing from sociologists and communication theorists, education theorists have expounded on theories of boundary crossing in order to delineate the process and benefits of working in collaborative partnerships with P-12 schools (Akkerman \& Baker, 2011). The concept of boundary crossing is prominent in at least two strains of education learning theories: cultural historical activity theory on expansive learning (CHAT) (Engestrom, 1987), and situated learning theory in communities of practice (Wenger, 1998). This research represents a growing appreciation of diversity in which postmodernism, poststructuralism, postcolonialism, and feminism focus on the margins in order to decenter discourses of power (Akkerman \& Baker, 2011).

Theories of boundary crossing value differences. Rather than perceiving sociocultural difference as something to be avoided or overcome, engaging across differences is viewed as necessary, with diversity recognized as a vital force for change and development. Following this educational theory, boundaries are potential learning resources that depend on multiple perspectives from multiple parties (Akkerman \& Baker, 2011). Such a concept is one example of education theory that meets the postpandemic moment. In alignment with social justice movements, boundary crossing theory works at the edges of societies and groups.

Furthermore, boundary crossing theory does not promise an easy answer to challenges of diverse views, a vital perspective in our current moment of contested opinions. Rather than giving simplistic calls for agreement, boundary crossing theory acknowledges the potential difficulty of action and interaction across systems, while at the same time emphasizing the value of communication and collaboration. Boundary crossing does not mean imposing ideas from one side of the boundary to the other. Instead, this educational theory accepts that differences will remain, and celebrates this fact. Difference encountered at the boundary is where learning occurs. Following this model, ITE and cooperating teachers both have contributions to make as well as potential knowledge to gain from each other at the boundary between the two institutions.

In addition to examining the university and school relationships, a great deal of research has considered the process of taking students across the boundary of the university context into the local school context and the resulting translation of practice that must occur (Willard-Holt, 2001; Smith \& Lev-Ari, 2005; Pence \& Macgillivray, 2008; Kissock \& Richardson, 2010; DiFrancesco et al., 2019; Newton et al., 2020; Whatley et al., 2020). In fact, teacher education has a long tradition of training teacher candidates to respectfully navigate border crossing between the university setting and the local school. Calls for boundary crossing competence or boundary skills draw attention to the necessary preparation and debriefing that must occur in order to facilitate this negotiation and dialogic relationship. These skills are vital not only for the university faculty and the cooperating teacher, but also for the preservice teacher engaging across these boundaries.

Given this robust body of literature and practice in ITE, we might expect to see these same concepts and practices brought to bear on practices aimed at GCE. However, as we will see, the neoliberal context of internationalization practice in higher education has proved a pernicious barrier to innovation and has infected some practices, such as study abroad, for preservice teachers. 


\section{Prepandemic study abroad for preservice teachers}

In recent decades, teacher educators have established numerous practices to encourage the development of GCE and related concepts in preservice teachers (Harshman et al., 2015). For this discussion, we consider study abroad, one prominent intervention in teacher education with demonstrated benefits long into participants' teaching careers (Stachowski \& Sparks, 2007; Marx \& Moss, 2011; Salmona et al., 2015; He et al., 2017; Mikulec, 2019). Study abroad, or education abroad, has been shown to instill global and intercultural competencies in preservice teachers (Cushner \& Mahon, 2002; Cushner \& Brennan, 2007; Mansilla \& Jackson, 2011; Pilonieta et al., 2017; Morley et al., 2019). Researchers have shown study abroad programs to be opportunities for growth and reflection related to GC concepts (Willard-Holt, 2001; Pence \& Macgillivray, 2008; Kissock \& Richardson, 2010; Harshman et al., 2015). Even short-term study abroad programming has been shown to bring GC-related benefits such as perspective taking, empathy, and reflection (Banks, 2008; van Driel et al., 2016).

At the same time, studies have demonstrated limitations of study abroad programs, finding that gaps in the programming can be a remedy worse than the ailment (Santoro \& Major, 2012). A growing body of research finds that without careful and sensitive marketing and recruitment, rigorous accompanying academic work, and a careful selection of placement schools, education abroad can be seen as primarily an opportunity to travel to an exotic tourist destination and view the locals from the safe distance of the metaphorical veranda (Ogden, 2007; Santoro, 2014). Neoliberal framing sets up the privileged travelers as people with the option of exploiting environmental and other resources for their personal gain. In fact, study abroad planners lament that students continue to demand increasing levels of the comforts of home during the experience (Ogden, 2007). Infused with narratives of the personal benefits of the experience, as well as long-term career benefits to the participants, study abroad becomes an extension of the "business of education", an expensive upgrade or add-on for those who can afford it.

Without attention to multiple factors, study abroad programs for preservice teachers can devolve into academic tourism or voluntourism, what Shultz calls radical GCE. Rather than engendering transformationalism through GCE, study abroad programs risk actually fostering postcolonial and neocolonial racist attitudes, setting preservice teachers up as the "White saviors" or employing other narratives of privilege and rescue. Participants come to help the international host practicing teachers without recognizing that, as inexperienced preservice teachers themselves, they may have little to offer beyond economic benefits (Major \& Santoro, 2016). In addition to the disservice to participants, such programming can damage equitable international partnerships. Obviously educators do not want their school treated as a tourist destination, and resist or resent participating in academic tourism (Breen, 2012). Moreover, host teachers can themselves internalize this perspective and feel they have little to offer to the visiting preservice teachers (Major \& Santoro, 2016).

In addition to challenges associated with the preparation and outcomes, preservice teachers' overall participation in study abroad remains low and unevenly distributed. Taking the US as an example of broader trends, according to the Institute of International Education (IIE, 2019), from 2007 to 2018, only three to four percent of US undergraduate study abroad participants were education students. Moreover, US undergraduates who do study abroad are overwhelmingly White, with students of color disproportionately underrepresented (Lee \& Green, 2016; Chama et al., 2018; Rhein, 2018). 
One reason for the lack of broader participation among teacher education students is the nature of the ITE program itself. Teacher licensing is local, with specific requirements determined by each nation or region. This local orientation means that courses abroad often do not count toward degree requirements, and licensure requirements may not leave much time for preservice teachers to engage in study abroad (Cushner \& Mahon, 2002).

Notably, the greatest barrier to study abroad participation is additional costs of the programs. Many study abroad programs require students to take on travel costs in addition to the already high costs of higher education. The financial burden means lower participation overall and participation by only the privileged few preservice teacher candidates with both the financial resources and cultural capital to realize the potential of international travel. The inequities resulting from the high costs of study abroad are evident across the study abroad programming spectrum in all disciplines in US higher education, setting up an especially troubling situation in teacher education.

Research confirms that US teacher candidates tend to return to their home communities to build their teaching career, what has been called the "draw to home" (Engel \& Cannata, 2015). This reality adds a special imperative to find pedagogical approaches to preparing equitable and accessible GCE for preservice teachers. If, following higher education's internationalization strategies, ITE relies on study abroad as one primary means of developing GCE, then great inequities will remain. Only those preservice teachers coming from, and likely returning to, districts of privilege will have the opportunity to participate in this form of GCE, and thus to bring that benefit to their future students. Such a reality significantly curtails the emancipatory potential of GCE developed in study abroad. If GCE remains a luxury for those who can afford it, it remains relegated to spaces where it may continue to manifest only as a luxury add-on. Worse, in contexts where only privileged teachers and districts are able to participate, the program itself then models the inequality it sets out to address. Preservice teachers are cast as saviors rescuing those in less affluent regions of the world, rather than equals collaborating with them.

Many of the challenges presented here are not specific to study abroad in teacher education but are broadly characteristic of all study abroad in higher education both in the US and, to varying degrees, globally. However, as noted, the inequities of study abroad are particularly egregious when applied to ITE since they tend to be reproduced when preservice teachers return to their home community. While certainly there have been many calls from scholars and practitioners alike to reform and improve study abroad practice in higher education, the neoliberal structure infecting higher education limits possibilities of transformation.

\section{Higher education internationalization and GCE for preservice teachers}

Numerous studies have considered the impact of nongovernmental organizations (NGOs) on teacher preparation for GCE, demonstrating their prevalence and influence on US teacher education in particular, though in other national contexts as well (Mundy \& Manion, 2008; Gaudelli, 2016). However, less consideration has been given to how higher education internationalization practice affects the GCE efforts of teacher education. This context is vital to consider, given the prevalence globally of university-based teacher education, which remains the gold standard in most of the world.

Universities of teacher education create and vet nearly all knowledge of K-12 curriculum worldwide. While there is some debate around alternative models of teacher training, these debates are outside the scope here. Instead, this article considers the 
impact of the higher education internationalization's structural context on efforts to provide GCE to all teacher education candidates in university-based teacher education.

In countries where teacher education is situated within higher education, efforts to provide study abroad and other global initiatives have occurred in the context of higher education internationalization practices. While programming may follow disciplinelevel goals, legal and budgetary standards tend to be under the purview of universitylevel operations. To some degree, standardization across study abroad practice has become the norm in order to maximize efficiencies of scale and to establish expertise. In fact, arguments for this specialization come from within university international education, as practitioners have worked to establish their place as experts setting the standards for international programming, including study abroad (Wiseman \& Matherly, 2009).

Globally, higher education internationalization policies claim to prepare graduates as global citizens (Clifford \& Montgomery, 2017). However, large bodies of research document the myriad ways that higher education institutions are steeped in neoliberal practices, marked by a market rationality and the idea of an "entrepreneurial citizen" (Burbules \& Torres, 2000; Popkewitz, 2007). Current global conditions are laying bare the contradictions of higher education internationalization more starkly than ever, as financial pressures are pushing institutions toward market-based, competitive, and uneven interpretations of internationalization. Critics question whether the more emancipatory goals of GCE can be achieved under the imperatives of neoliberal market-driven practices. These contradictions have led some researchers to argue for a more critical and theoretical approach to the underlying neoliberal assumptions of GCE (Andreotti, 2006; Pashby, 2011). Universities are becoming increasingly corporate in financial structure, evaluation metrics, management style, personnel, advertising, and promotions (Brown, 2011). The neoliberal GCE found in the university context promotes globalization of the capitalist economy by serving the interests of global economic structures. Giroux has called out this phenomenon as "business engaged in education", where students are cast as consumers conceiving of higher education as a personal investment in their own future earning capacity (Brown, 2011). Within this context, study abroad targets those from a privileged social background, making it an exclusive concept that wavers between what Shultz defined as neoliberal GCE and radical GCE. Study abroad thus separates those in the position of helping and those in need of help, casting the latter as "an object of benevolence" (Jefferess, 2008). In either version, current neoliberal structures are maintained and treated as unassailable.

Well before the pandemic, efforts were underway to reimagine internationalization of higher education toward GCE (Bosio, 2017; Bosio \& Torres, 2019; Bosio, 2020). Scholars called for a profound epistemological shift to unshackle global citizenship education from the dominant neoliberal political and economic practices that reproduce social inequalities through privileging the elite in a global education marketplace. For example, Andreotti (2011) argues that global citizenship educators need to unpack static ideals predicated upon historically European worldviews that glorify their perspectives internationally. Multiple other researchers and scholars have similarly called for a dramatic epistemological shift. However, taking study abroad as one example of a practice aimed at developing global citizenship, the halt and then restart of study abroad during the pandemic clearly demonstrates how difficult such reform may be, given the seemingly immutable neoliberal structures that undergird higher education. 


\section{Higher education's internationalization during the pandemic}

Higher education's response to the pandemic in study abroad is instructive because it reveals the challenge of engaging in innovative practices aimed at GCE within a higher education context that is steeped in neoliberal structures and profit imperatives. Further, it establishes the need to reimagine, not return to, previous practice.

The pandemic disrupted higher education globally on an unprecedented scale. Like $\mathrm{K}-12$ education, higher education around the world partially or completely closed, often operating online, while periodically closing residence halls and other portions of campuses in the face of outbreaks. Many higher education internationalization efforts, in particular, were almost completely halted, with student mobility at first stalled and then stopped.

Beginning in March 2020, nearly all students studying outside their home country were forced to suddenly return or risk being trapped in the host country for an unknown duration. This sudden exodus meant unprecedented academic disruption for students globally. For part of the world, including Europe and the US, this disruption occurred mid-semester. Some students were able to stay enrolled and complete coursework online while others had to forfeit the semester completely.

In most cases, as is typical for student mobility in general, this sudden travel requirement occurred at the students' expense, with varying degrees of housing expenses or program costs being shared among the students and the home and host institutions. The financial ramifications were enormous for students, but also for universities worldwide, as well as related organizations, with many for-profit study abroad program and service providers folding under the financial hit of suddenly closing.

As borders remained closed, universities scrambled to provide longer-term alternatives for their enrolled international students as well as for students who had planned to be abroad in the future. As noted above, international student mobility represents a disruption of not only academic and GC goals, but also of an enormous industry.

In the US, some larger internationally networked campuses tapped their global networks to provide temporary housing and programming in "bridge programs" at partner campuses within the international students' home countries. Such programs meant that students were housed in local in-country campuses while attending US university courses online. US students might encounter their international peers in these online classes, but in this arrangement obviously much of the cross-cultural engagement that usually occurs on campus is limited for both the international and the domestic students. While US universities were able to retain portions of their international tuition funding in this temporary model, many GCE goals for all students have been partially forfeited or at least postponed.

As border closings dragged on and travel remained disrupted, universities looked for online programming that could in some way provide a short-term facsimile of education abroad. The costs for such programming were often borne by the student: university administrators found this arrangement necessary to financially support partner institutions and providers that depend on the funding of hosting students. The result was again that students paid to remain in their home country with online programming provided by a host institution. The degree to which GCE goals were being met is unclear and, to date, largely under-studied, but the program providers were able to retain portions of the funding they would have had without the pandemic. Clearly much of the careful planning and operation that is so critical in study abroad was forfeited in an effort to preserve the financial model that sustained many of the higher education international partnerships and related industries. 
Certainly such efforts to provide some kind of ongoing academic programming for students caught in the lurch of the pandemic are commendable, yet it's clear that many of the GCE outcomes were largely sacrificed while the financial gains to host institutions were at least partially retained. Much of the cost of the sudden disruption was unevenly distributed, with large, prestigious universities taking on larger proportions of the costs, while students from less-funded institutions were left picking up the costs for flights home and remaining program expenses. In all cases, students took on the majority of the personal expenses.

This global disruption reveals much about the status of GCE within study abroad as well as the seemingly incontrovertible structures that sustain internationalization programming in higher education. In the current context, study abroad in many parts of the world finds itself shelved, suggesting its continued status as an add-on or extra place in the curriculum (Mundy \& Manion, 2008). Moreover, the neoliberal priority of the profit imperative has been preserved to some extent during these pandemic study abroad measures, even though the GCE goals were largely surrendered.

\section{Boundary crossing as a transformation}

The example above illustrates the tenacity of the neoliberalism pervading higher education, yet the highest quality ITE globally remains university based. Therefore, ITE must consider and mitigate the neoliberalism bleeding into GCE for preservice teachers. Returning to our example, I argue that study abroad for ITE should not go back to prepandemic normal. If ITE is to harness the proven value of study abroad for GCE development in preservice teachers, the model of study abroad must be reimagined to find a more equitable, accessible approach. In fact, such models already exist in teacher education, but have previously been underutilized in study abroad programming for GCE.

I argue that teacher educators can draw on boundary crossing theory to reimagine study abroad aimed at GCE as an expansion of the school community-based learning that already occurs. ITE should approach education abroad for GCE as an expansion of the school community into the broader global community. They should engage in practices similar to those developed with local partnerships and respectful boundary crossing. Rather than working from higher education's contested model of global engagement mired in neoliberal structures, teacher education should work from its own research documenting how learning occurs.

If we apply such theories to our example here of study abroad, boundary crossing would enable a reimagination of the relationship between host and participant. The neoliberal approach does not engage across the boundary nor imagine any benefit in doing so. Instead, participants purchase the experience as a way to increase future employability or future earnings. By "staying on the veranda", participants keep a safe distance from the discontinuity that boundary crossing theories advocate. Conversely, if we compare to radical GCE, boundary crossing theory eliminates the risk of slipping into a postcolonial goal of changing those encountered at the host site, "updating" their practice or "improving" their lives in some material way. Boundary crossing theories do not advocate attempts to reform across the boundary, but instead encourage a reflexive desire to understand and learn on each side of the boundary itself.

Study abroad could be redesigned, but it must first be reimagined outside of higher education models. This transformation would require both more affordable and more accessible programming. Short-term programming remains contested in higher education contexts, but shorter travel times fit within education degree requirements and can be more 
affordable. Moreover, models of short-term exchange, including local homestays, could go a long way to further reducing program costs. Innovative programming would require both sending institutions and host institutions to think about the programs differently. Host establishments and program providers would not be able to reap financial rewards. Sending institutions would have to reevaluate legal structures that encourage the liability protection of third-party providers. Institutions would have to restructure fees in order to manage costs. Transformational programs would not follow the neoliberal study abroad for-profit model, but instead would follow boundary crossing models where both sending and host institutions participate for shared benefit in the profession and, ultimately, in the global public good.

Reimagining study abroad based on boundary crossing theory is just one example of how GCE can be transformed for ITE. By engaging international partners in the same way that teacher education engages with local schools, teacher educators themselves begin to model GC. This transformationalism in GCE would allow educators to completely reimagine patterns of inclusion and exclusion, as well as new forms of engagement. Transformationalist GCE would not be content to only challenge unjust structures, but instead would reimagine inclusive community and recognize the link between the local experience and the shared global experience. In this way, teacher education can demonstrate that education must serve both local and global goals, that local can never be wholly separate from global, and that all subjects, all teachers, and all students require a robust education in both realms of citizenship, local and global.

Such global restructuring is a daunting project requiring a comprehensive reimagining of global education practice. Yet, without such a sweeping overhaul, we will continue to reproduce prepandemic structures with ongoing inequitable results. As we have discussed, typically only privileged preservice teachers were afforded the luxury of interventions like study abroad to develop GCE skills. Then those privileged few were likely to return that private good back to the more privileged schools they came from originally. If we approach study abroad for GCE from a transformationalist perspective, we can reimagine who it is for and what it can do. Study abroad is just one example of the way we can transform GCE if we guard teacher education from the neoliberalism in higher education.

Instead of returning to old neoliberal paradigms, we must train teachers globally to collaborate, understand, and advocate for each other in transnational, transformational networks of solidarity. Teacher educators should not treat incoming preservice teachers as a funding source but instead should view their training as a professional development opportunity and a part of our own obligation as global citizens. Such repositioning means the global north and global south must redefine their relationship to each other: they must exist outside a marketplace and enter into a more equitable collaboration based on the mutual investment in the global profession of teaching. We must behave as global citizens in education, working together in the project of training teachers globally, accepting that responsibility as part of the global good.

\section{References}

Akkerman, S. F., \& Bakker, A. (2011). Boundary crossing and boundary objects. Review of Educational Research, 81(2), 132-169. https://doi.org/10.3102/0034654311404435.

Andreotti, V. (2006). "Theory without practice is idle, practice without theory is blind": The potential contributions of post-colonial theory to development education. Development Education Journal, 12(3), 7-10. https://think-global.org.uk/wp-content/uploads/dea/documents/dej_12_3_andreotti.pdf. 
Andreotti, V. (2011). Actionable postcolonial theory in education. Springer.

Andreotti, V. (2015). Global citizenship education otherwise: Pedagogical and theoretical insights. In A. A. Abdi, L. Shultz, \& T. Pillay (Eds.), Decolonizing global citizenship education (pp. 221-229). Brill Sense.

Banks, J. A. (2008). Diversity, group identity, and citizenship education in a global age. Educational Researcher, 37(3), 129-139.

Bosio, E. (2017). Educating for global citizenship and fostering a nonkilling attitude. In J. Evans Pim \& S. Herrero Rico (Eds.), Nonkilling education (pp. 59-70). Center for Global Nonkilling.

Bosio, E. (2020). Towards an ethical global citizenship education curriculum framework in the modern university. In D. Bourn (Ed.), The Bloomsbury handbook of global education and learning (pp. 187-206). Bloomsbury.

Bosio, E., \& Torres, C. A. (2019). Global citizenship education: An educational theory of the common good? A conversation with Carlos Alberto Torres. Policy Futures in Education, 17(6), 745-760. https://doi.org/10.1177/1478210319825517.

Bourn, D., Hunt, F., \& Bamber, P. (2017). A review of education for sustainable development and global citizenship education in teacher education. Global Education Monitoring Report background paper. UNESCO. https://discovery.ucl.ac.uk/id/eprint/10030831/1/bournhuntbamber.pdf

Breen, M. (2012). Privileged migration: American undergraduates, study abroad, academic tourism. Critical Arts, 26(1), 82-102. https://doi.org/10.1080/02560046.2012.663163.

Brown, R. (2011). What do we do about university governance? Perspectives: Policy and Practice in Higher Education, 15(2), 53-58. https://doi.org/10.1080/13603108.2011.573007.

Burbules, N. C., \& Torres, C. A. (Eds.) (2000). Globalization and education: Critical perspectives. Psychology Press.

Chama, S., Ramirez, O., \& Mutepa, R. (2018). Perceived barriers to interning abroad: Perceptions from African American social work students. Journal of Student Affairs Research and Practice, 55(3), 321-333. https://doi.org/10.1080/19496591.2018.1474751.

Clarke, A., Triggs, V., \& Nielsen, W. (2014). Cooperating teacher participation in teacher education: A review of the literature. Review of Educational Research, 84(2), 163-202. https://doi.org/10.3102/ 0034654313499618.

Clifford, V., \& Montgomery, C. (2017). Designing an internationalised curriculum for higher education: Embracing the local and the global citizen. Higher Education Research and Development, 36(6), 1138-1151. https://doi.org/10.1080/07294360.2017.1296413.

Cushner, K., \& Brennan, S. (2007). Intercultural student teaching: A bridge to global competence. Rowman \& Littlefield.

Cushner, K., \& Mahon, J. (2002). Overseas student teaching: Affecting personal, professional, and global competencies in an age of globalization. Journal of Studies in International Education, 6(1), 44-58. https://doi.org/10.1177/1028315302006001004.

DiFrancesco, D., Kochlefl, M. K., \& Walker, J. (2019). Fostering inclusive teaching: A systemic approach to develop faculty competencies. Journal of Higher Education Theory and Practice, 19(1), 31-43. https://doi.org/10.33423/jhetp.v19i1.666

Engel, M., \& Cannata, M. (2015). Localism and teacher labor markets: How geography and decision making may contribute to inequality. Peabody Journal of Education, 90(1), 84-92. https://doi.org/ 10.1080/0161956X.2015.988533.

Engestrom, Y. (1987). Learning by expanding. Orienta-Konsultit Oy.

Fives, H., Mills, T. M., \& Dacey, C. M. (2016). Cooperating teacher compensation and benefits: Comparing 1957-1958 and 2012-2013. Journal of Teacher Education, 67(2), 105-119. https://doi.org/ $10.1177 / 0022487115626428$.

Gaudelli, W. (2009). Heuristics of global citizenship discourses towards curriculum enhancement. Journal of Curriculum Theorizing, 25(1), 68-85. https://journal.jctonline.org/index.php/jct/article/view/ GAUDHEU

Gaudelli, W. (2016). Global citizenship education: Everyday transcendence. Routledge.

Goren, H., \& Yemini, M. (2016). Global citizenship education in context: Teacher perceptions at an international school and a local Israeli school. Compare: A Journal of Comparative and International Education, 46(5), 832-853. https://doi.org/10.1080/03057925.2015.1111752.

Goren, H., \& Yemini, M. (2017). Citizenship education redefined: A systematic review of empirical studies on global citizenship education. International Journal of Educational Research, 82, 170183. https://doi.org/10.1016/j.ijer.2017.02.004.

Harshman, J., Augustine, T., \& Merryfield, M. (2015). Research in global citizenship education. Information Age. 
He, Y., Lundgren, K., \& Pynes, P. (2017). Impact of short-term study abroad program: Inservice teachers' development of intercultural competence and pedagogical beliefs. Teaching and Teacher Education, 66, 147-157. https://doi.org/10.1016/j.tate.2017.04.012.

IIE [Institute of International Education] (2019). Open doors 2019: Report on international education exchange. https://www.iie.org/Research-and-Insights/Publications/Open-Doors-2019.

Jefferess, D. (2008). Global citizenship and the cultural politics of benevolence. Critical Literacy: Theories and Practices, 2(1), 27-36. http://criticalliteracy.freehostia.com/index.php?journal=criticalliteracy\& page $=$ article \&op $=$ view $\&$ path $\% 5 \mathrm{~B} \% 5 \mathrm{D}=5 \&$ path $\% 5 \mathrm{~B} \% 5 \mathrm{D}=8$.

Kissock, C., \& Richardson, P. (2010). Calling for action within the teaching profession: It is time to internationalize teacher education. Teaching Education, 21(1), 89-101. https://doi.org/10.1080/1047621090 3467008 .

Lee, J. A., \& Green, Q. (2016). Unique opportunities: Influence of study abroad on Black students. Frontiers: The Interdisciplinary Journal of Study Abroad, 28(1), 61-77. https://doi.org/10.36366/frontiers. v28i1.380

Major, J., \& Santoro, N. (2016). Supervising an international teaching practicum: Building partnerships in postcolonial contexts. Oxford Review of Education, 42(4), 460-474. https://doi.org/10.1080/03054985. 2016.1195734.

Mansilla, V. B., \& Jackson, A. (2011). Multiculturalism and the postmodern critique: Towards a pedagogy of resistance and transformation. Cultural Studies, 7(1), 118-146. https://doi.org/10.1080/0950238930 0490101.

Marx, H., \& Moss, D. M. (2011). Please mind the culture gap: Intercultural development during a teacher education study abroad program. Journal of Teacher Education, 62(1), 35-47. https://doi.org/10.1177/ 0022487110381998.

Mikulec, E. (2019). Short-term study abroad for pre-service teachers: Personal and professional growth in Brighton, England. International Journal for the Scholarship of Teaching and Learning, 13(1), 1-12. https://doi.org/10.20429/ijsotl.2019.130111

Morley, A., Braun, A. M., Rohrer, L., \& Lamb, D. (2019). Study abroad for preservice teachers: A critical literature review with considerations for research and practice. Global Education Review, 6(3), 4-29. https://ger.mercy.edu/index.php/ger/article/view/521.

Mundy, K., \& Manion, C. (2008). Global education in Canadian elementary schools: An exploratory study. Canadian Journal of Education, 31(4), 941-974. https://eric.ed.gov/?id=ej830510.

Newton, J., Oudghiri, S., Obenchain, K., \& Phillion, J. A. (2020). Preservice teachers' understandings of social justice within the context of study abroad programs. Theory into Practice, 59(3), 259-268. https://doi.org/10.1080/00405841.2020.1739956.

Norman, P. J. (2011). Planning for what kind of teaching? Supporting cooperating teachers as teachers of planning. Teacher Education Quarterly, Summer, 49-68. https://www.jstor.org/stable/23479617.

Ogden, A. (2007). The view from the veranda: Understanding today's colonial student. Frontiers: The Interdisciplinary Journal of Study Abroad, 15(1), 35-56. https://files.eric.ed.gov/fulltext/EJ878378.pdf.

Oxley, L., \& Morris, P. (2013). Global citizenship: A typology for distinguishing its multiple conceptions. British Journal of Educational Studies, 61(3), 301-325. https://doi.org/10.1080/00071005.2013. 798393.

Pashby, K. (2011). Cultivating global citizens: Planting new seeds or pruning the perennials? Looking for the citizen-subject in global citizenship education theory. Globalisation, Societies and Education, 9(34), 427-442. https://doi.org/10.1080/14767724.2011.605326.

Pashby, K., da Costa, M., Stein, S., \& Andreotti, V. (2020). A meta-review of typologies of global citizenship education. Comparative Education, 56(2), 144-164. https://doi.org/10.1080/03050068.2020. 1723352.

Pence, H. M., \& Macgillivray, I. K. (2008). The impact of an international field experience on preservice teachers. Teaching and Teacher Education, 24(1), 14-25. https://doi.org/10.1016/j.tate.2007.01.003.

Pilonieta, P., Medina, A. L., \& Hathaway, J. I. (2017). The impact of a study abroad experience on preservice teachers' dispositions and plans for teaching English language learners. The Teacher Educator, 52(1), 22-38. https://doi.org/10.1080/08878730.2016.1247204.

Popkewitz, T. S. (2007). Alchemies and governing: Or, questions about the questions we ask. Educational Philosophy and Theory, 39(1), 64-83. https://doi.org/10.1111/j.1469-5812.2007.00240.x.

Rhein, D. (2018). African American student sociocultural adjustment to Thai international higher education. Globalisation, Societies and Education, 16(4), 381-394. https://doi.org/10.1080/14767724.2018. 1440349.

Salmona, M., Partlo, M., Kaczynski, D., \& Leonard, S. N. (2015). Developing culturally competent teachers: An international student teaching field experience. Australian Journal of Teacher Education, 40(4), 35-53. https://doi.org/10.14221/ajte.2015v40n4.3. 
Santoro, N. (2014). "If I'm going to teach about the world, I need to know the world": Developing Australian pre-service teachers' intercultural competence through international trips. Race Ethnicity and Education, 17(3), 429-444. https://doi.org/10.1080/13613324.2013.832938.

Santoro, N., \& Major, J. (2012). Teaching education learning to be a culturally responsive teacher through international study trips: Transformation or tourism? Teaching Education, 23(3), 309-322. https://doi. org/10.1080/10476210.2012.685068.

Shultz, L. (2007). Educating for global citizenship: Conflicting agendas and understandings. Alberta Journal of Educational Research, 53(3), 248-258. https://eric.ed.gov/?id=EJ779989.

Smith, K., \& Lev-Ari, L. (2005). The place of the practicum in pre-service teacher education: The voice of the students. Asia-Pacific Journal of Teacher Education, 33(3), 289-302. https://doi.org/10.1080/ 13598660500286333.

Stachowski, L., \& Sparks, T. (2007). Thirty years and 2,000 student teachers later: An overseas student teaching project that is popular, successful, and replicable. Teacher Education Quarterly, 34(1), 115132. https://files.eric.ed.gov/fulltext/EJ795147.pdf.

van Driel, B., Darmody, M., \& Kerzil, J. (2016). Education policies and practices to foster tolerance, respect for diversity and civic responsibility in children and young people in the EU. Neset Ii Report. https:// op.europa.eu/en/publication-detail/-/publication/abe4b8dc-ffa8-11e5-b713-01aa75ed71a1/langu age-en.

Wenger, E. (1998). Communities of practice: Learning as a social system. Systems Thinker, 9(5), 2-3. https://participativelearning.org/pluginfile.php/636/mod_resource/content/3/Learningasasocialsystem. pdf.

Whatley, M., Landon, A. C., Tarrant, M. A., \& Rubin, D. (2020). Program design and the development of students' global perspectives in faculty-led short-term study abroad. Journal of Studies in International Education, 25(3), 301-318. https://doi.org/10.1177/1028315320906156.

Willard-Holt, C. (2001). The impact of a short-term international experience for preservice teachers. Teaching and Teacher Education, 17(4), 505-517. https://doi.org/10.1016/S0742-051X(01)00009-9.

Wiseman, A. W., \& Matherly, C. (2009). The professionalization of comparative and international education: Promises and problems. Research in Comparative and International Education, 4(4), 334-355. https://doi.org/10.2304/rcie.2009.4.4.334.

Yemini, M., Tibbitts, F., \& Goren, H. (2019). Trends and caveats: Review of literature on global citizenship education in teacher training. Teaching and Teacher Education, 77, 77-89. https://doi.org/10.1016/j. tate.2018.09.014.

Yuan, R., \& Yang, M. (2020). Understanding university-based teacher educators' boundary crossing experiences: Voices from Hong Kong. Teachers and Teaching: Theory and Practice, 26(2), 193-213. https:// doi.org/10.1080/13540602.2020.1777961.

Publisher's Note Springer Nature remains neutral with regard to jurisdictional claims in published maps and institutional affiliations.

\footnotetext{
Allison Witt is the Director of International Programs in the College of Education at the University of Illinois Urbana-Champaign. She is an Associate Teaching Professor in Global Studies in Education and is the Program Leader for the International Education Administration and Leadership Graduate program. She is the Director of the IGlobal Club, a virtual extracurricular activity that links preservice teachers to middle school students globally in the study of the UN Sustainable Development Goals. Allison is a former Assistant Director of Academic Affairs at the Illinois Board of Higher Education, where she contributed to state higher education policy in Illinois. She is the author of Shifting Tides in Global Higher Education (2011), published by Peter Lang. Allison earned a PhD in Education Policy Studies from the University of Illinois at Urbana-Champaign.
} 